Article

\title{
Swimming Pool Evaporative Water Loss and Water Use in the Balearic Islands (Spain)
}

\author{
Angela Hof ${ }^{1}\left(\mathbb{D}\right.$, Enrique Morán-Tejeda ${ }^{2, *} \mathbb{C}$, Jorge Lorenzo-Lacruz ${ }^{2}(\mathbb{D}$ and \\ Macià Blázquez-Salom ${ }^{2}$ (D) \\ 1 Department of Geography and Geology, University of Salzburg, 5020 Salzburg, Austria; angela.hof@sbg.ac.at \\ 2 Department of Geography, University of the Balearic Islands, 07122 Palma, Spain; \\ jorgelorenzolacruz@gmail.com (J.L.-L.); mblazquez@uib.cat (M.B.-S.) \\ * Correspondence: e.moran@uib.es; Tel.: +34-971-173-482
}

Received: 24 September 2018; Accepted: 12 December 2018; Published: 19 December 2018

\begin{abstract}
The Balearic Islands are a major Mediterranean tourist destination that features one of the greatest swimming pool densities within Europe. In this paper, standard meteorological data were combined with a diachronic swimming pool inventory to estimate water evaporation from swimming pools over the Balearic archipelago. Evaporation was estimated using an empirical equation designed for open-water surfaces. Results revealed a 32\% increase in swimming pools' water use by 2015. Evaporation from swimming pools added $9.6 \mathrm{~L}$ of water to touristic consumption per guest night and person, and represented $4.9 \%$ of the total urban water consumption. In 2015, almost $5 \mathrm{hm}^{3}$ ( 5 billion L) were lost from pools across the Balearic Islands. In several densely urbanized areas, evaporative water loss from pools exceeded four million litres per square kilometre and year. The water needed to refill the total of 62,599 swimming pools and to counteract evaporative water loss is equivalent to 1.2 pools per year. Swimming pools have rapidly proliferated across the islands. We have expounded on this development in view of much-needed responsible water management across the islands.
\end{abstract}

Keywords: swimming pools; evaporation; tourism; water resources; Mediterranean; water conservation

\section{Introduction}

\subsection{Study Area and Background}

The Balearic archipelago (Figure 1) ranks top among the Spanish Mediterranean tourist zones for hotel-based sun and sea package tourists [1,2]. In 2015, 12.5 million tourist arrivals were recorded (IBESTAT 2017b) in this top touristic destination, which has a temperate climate and attractive beaches, good accessibility and massive touristic infrastructure, including hotels and a large airport. Unfortunately, the tourist activity clashes with one of the most important socio-environmental issues of the territory: water scarcity [2-4]. 


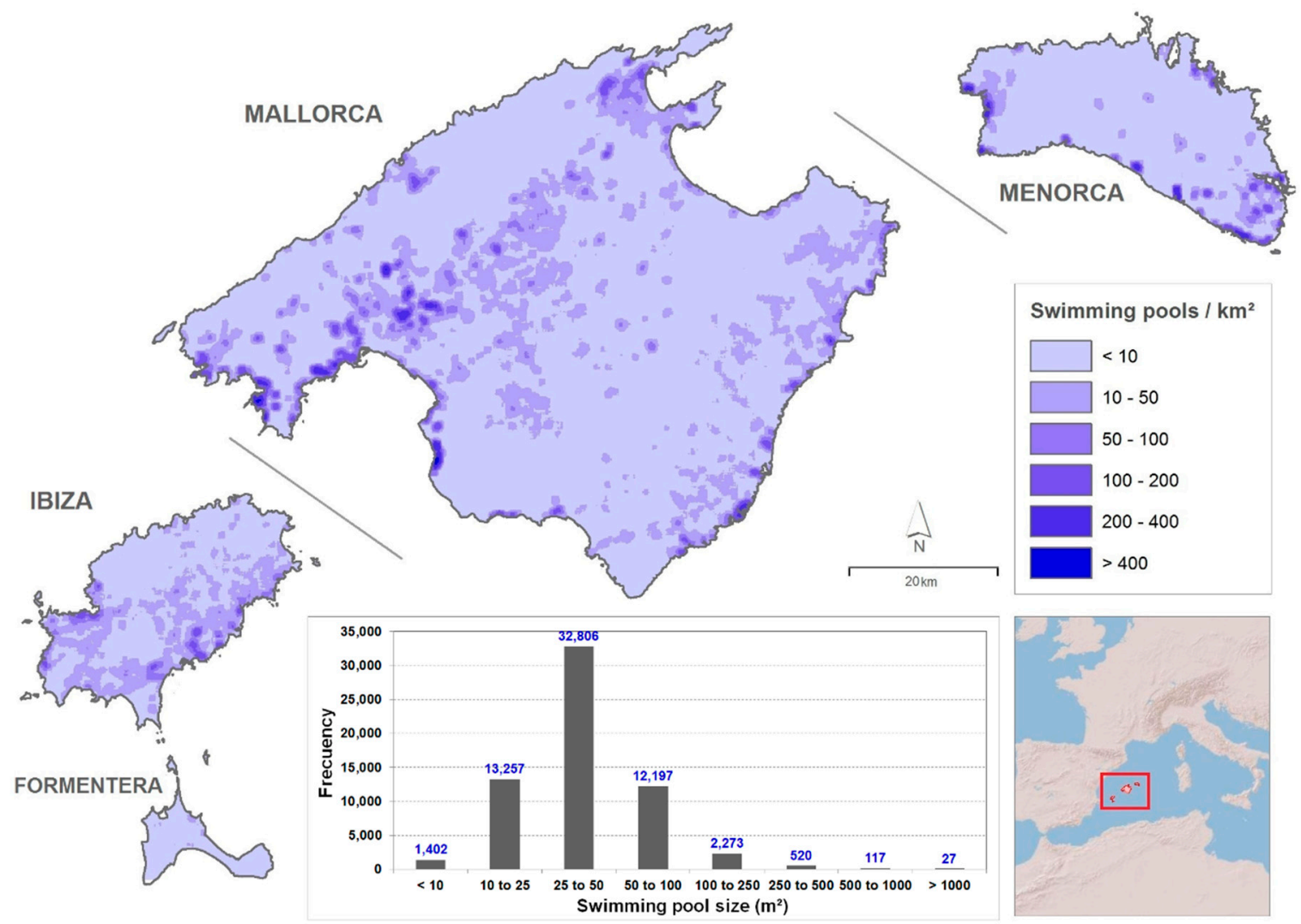

Figure 1. Location density and size class distribution of swimming pools in the Balearic Islands.

The Balearic Islands face a severe water supply problem, mainly during summer months. As a Mediterranean archipelago, climate drives natural variability in both seasonal and inter-annual precipitation, and this leads to frequent drought episodes [3] that may compromise water supply. The overexploitation and salinization of groundwater resources and the increasing dependence on desalinated water is well documented [5-8].The current mix of water sources on the islands reflects the technological and managerial approach to anthropogenic pressures on scarce water resources. Of the total water consumed, $74.95 \%$ is from groundwater bodies and only $2.95 \%$ from water reservoirs [9]. Treated wastewater contributes $12.44 \%$ of the water consumption, and desalinated water $9.66 \%$. Under the environmental objectives of the European Union's Groundwater Directive, half of the underground water bodies are classified as at-risk or severely overused [10]

Despite early warnings that the water supply could constrain further growth, the Balearic Islands have pioneered the rejuvenation and innovation of the Spanish tourism model that started in the early 1990s and that has exacerbated water use [6]. Residential or second-home tourism is an integral part of this socio-economic tourist modernization, and has contributed substantially to the accelerated urbanization of the Spanish Mediterranean coasts and islands [11]. As a result, these areas are currently characterized by urban sprawl, a high proportion of second homes, high per-capita water consumption levels and a high sensitivity to water shortages induced by climate change [2,12]. Under the leitmotif "quality tourism", development efforts over the last two decades stem from the successful marketing of the Balearic Islands as a residential tourism destination that responds to and creates holiday rental demands [13].

Under these conditions, the Balearic Islands face water "lock-in" in the water-dependent tourist and urbanization models, meaning that specific amounts of water are needed to keep hotels, swimming pools and second homes operational, irrespective of occupancy or use levels [14]. Water conservation policies are key instruments for ensuring sustainable water use, because a sufficient supply of water of adequate quality is indispensable to tourism, the islands' main economy. 


\subsection{The Importance of Swimming Pools for Increasing Water Consumption Levels in the Urban and Tourism Sectors}

Most environmental studies that focus on water consumption in areas with limited water resources (e.g., Southwestern USA, Spain) regard outdoor swimming pools as a major contributor to increasing water consumption levels in the urban and tourism sectors. Research into swimming pool water use is a component of a wide array of urban water sustainability studies that consider climate change, adaptation and uncertainty [15-20].

The presence of swimming pools increases water consumption levels in the residential sector [12,17-19,21,22]. This observation includes, but is not limited to, areas in which tourism has blended with demographic and urban growth to create a complex urbanization of entire coastal regions and island communities [2,12,22]. A study of Barcelona (Spain) revealed that adding a pool to the home increases water consumption by $155 \mathrm{~L}$ per day [23]. Even in humid countries such as Austria or Germany, a swimming pool increases water consumption by an average of $40 \mathrm{~L}$ per capita per day [24]. Deyà-Tortella et al. (2017) analysed water bills and showed that in Mallorca (Spain), the average water consumption in houses characterized by larger swimming pools or gardens with lawns was $254 \%$ and $178 \%$ of the corresponding values in semi-detached houses and single-family houses, respectively [25]. A study in South Africa estimated that the additional demand created by swimming pools was $2200-2400 \mathrm{~L} /$ month or $7 \%-8 \%$ of the total water demand [26]. Wentz and Gober (2007) [19] showed that on average, homes with swimming pools use more than twice as much water outdoors compared to homes without swimming pools in Phoenix, Arizona [19].

The proliferation of swimming pools marks a transition in urban water consumption and signifies broad changes in the urban and societal appropriation of resources. Particularly in the built environments of the coastal Mediterranean, swimming pools are connected with shifts in the urban lifestyles and an increase in residential tourism [12,13,22]. Residential tourism is now a global phenomenon that comprises the occasional use of a second home for vacation and recreation, including renting it out as a holiday home [27]. Since the mid 1990s, the extension of the Balearic Island tourist base by the proliferation of second homes, golf courses and yacht tourism has been marketed under the term "quality tourism" [28]. Quality tourism is increasing water demand for consumptive uses, such as the growing numbers of outdoors swimming pools or golf courses. Business-as-usual water policies are oriented to technological and supply solutions that rely on technological fixes such as the desalination of brackish groundwater and seawater. Meanwhile, other approaches to address this change in tourism and its increasing water demand are public policies to constrain urban sprawl. Regional and urban planning have already restricted new urban development, tourist accommodation supply and new golf courses or new villas in the countryside. Landscape preservation measures have also questioned the suitability of constructing more swimming pools in the designated areas. The objectives of the New Water Culture initiative is to manage water demand to make it more rational and efficient and to repair network leakages, while the conservation of the underground water bodies becomes the priority [10].

In summary, these findings highlight the importance of swimming pools in water consumption analyses and their relevance to the demand side of water management. Toward this end, there is a need to quantify the number of swimming pools in a given area and their role in that area's urban and tourist water consumption.

\subsection{Objectives and Structure of This Paper}

The present approach sought to reveal the current share and recent increase in pool water use in the urban water budgets of the Balearic Islands by estimating the evaporative loss of water from swimming pools. This analysis forms the basis for designed water use management and policy interventions that could reduce the size and numbers of swimming pools or promote the use of night covers and drainage barriers $[15,26]$. 
In addition to previous studies, which documented the proliferation of swimming pools in Mallorca [13] and their significance to water consumption at parcel, sub-municipal and household levels $[25,28]$, we broadened the scope of our study to a regional perspective. We aimed to measure the increase in swimming pools in the Balearic Islands of Ibiza, Formentera, Menorca, and Mallorca over the last decade, and assess the water metabolism of these swimming pools in terms of evaporative water loss. We use the term "water use" to label the volume of potable water that, due to evaporation, must be used to refill pools on a daily basis.

This paper is organized as follows: First, an approach to estimating the evaporation losses of swimming pools is outlined. Secondly, a separate model for swimming pools that receive shade through some part of the day is presented and discussed. This study outlines the spatial and temporal patterns exhibited by swimming pool water use and their role in urban water use budgets. Thirdly, the results are discussed and compared to the findings of similar studies.

\section{Material and Methods}

The following sections describe our approach to estimating water evaporation from swimming pools on a daily basis. This includes: (i) estimation of the daily water evaporation using meteorological station data, by means of the Penman equation for open-water surfaces [29]; (ii) spatial interpolation of the evaporation estimates to obtain an evaporation value for any location; (iii) calculation of water evaporation from swimming pools by multiplying the evaporation $\left(\mathrm{mm}\right.$ or $\left.\mathrm{L} \mathrm{m}^{-2}\right)$ at any given location by the existing pool area $\left(\mathrm{m}^{2}\right)$. This approach enables computation of the evaporation from any swimming pool on a daily, monthly, or seasonal basis, which provides higher spatial and temporal resolution than the use of annual evaporation data provided at a regional scale [12].

\subsection{Climate Data}

Meteorological data gathered by the Spanish Meteorological Agency (AEMET, Agencia Estatal de Meteorología) were used to calculate the evaporation volumes from open-water surfaces. These data comprised daily records of maximum and minimum temperature $\left({ }^{\circ} \mathrm{C}\right)$, maximum and minimum relative humidity $(\%)$, daily average wind speed $\left(\mathrm{m}^{2} \mathrm{~s}^{-1}\right)$ and daily global radiation $\left(\mathrm{MJ} \mathrm{m}^{-2}\right.$ day $\left.^{-1}\right)$ over the period 2006-2015. Data from a total of 16 automatic meteorological stations were used: 11 on the island of Mallorca, 2 on Ibiza, 2 on Menorca and 1 on Formentera. Not all stations measured the aforementioned variables, as most automatic stations managed by the AEMET measure only temperature and/or precipitation. Moreover, within the 2006-2015 period, some daily data were missing. In the cases in which missing data comprised less than $5 \%$ of the total data, gaps were filled by means of least square linear regressions using data from proximal stations as a predictor, but only when the Pearson's correlation coefficient between the candidate station (i.e., the station with data gaps) and the predictor station (i.e., the station without gaps) was $R>0.7$ [30].

\subsection{Diachronic Mapping and Swimming Pool Surface Measurements Using Cadastral Information}

A reliable inventory of swimming pools can be developed through the manual digitization of high-resolution aerial images [12]. Over larger areas, cadastral data can be used to reliably map swimming pools and their surface area [31].

Cadastres in Spain, first defined in 2004, are administrative registers that determine land ownership for taxation purposes [32]. The description of each parcel must include the location and the 20-digit cadastral reference, the area and uses, the condition of the buildings, the number of floors, a graphical representation, the economic cadastral value and the identification of the holder. Swimming pools are assigned their own category of land use, differentiated from ponds and other structures (Figure 2). The Virtual Office of the Cadastre (VOC) [33] grants public access to download municipal polygon layers in shapefile format and tables containing all cadastral alphanumeric information, except for the cadastral value and details that might reveal the identity of the holder of each plot [32]. 

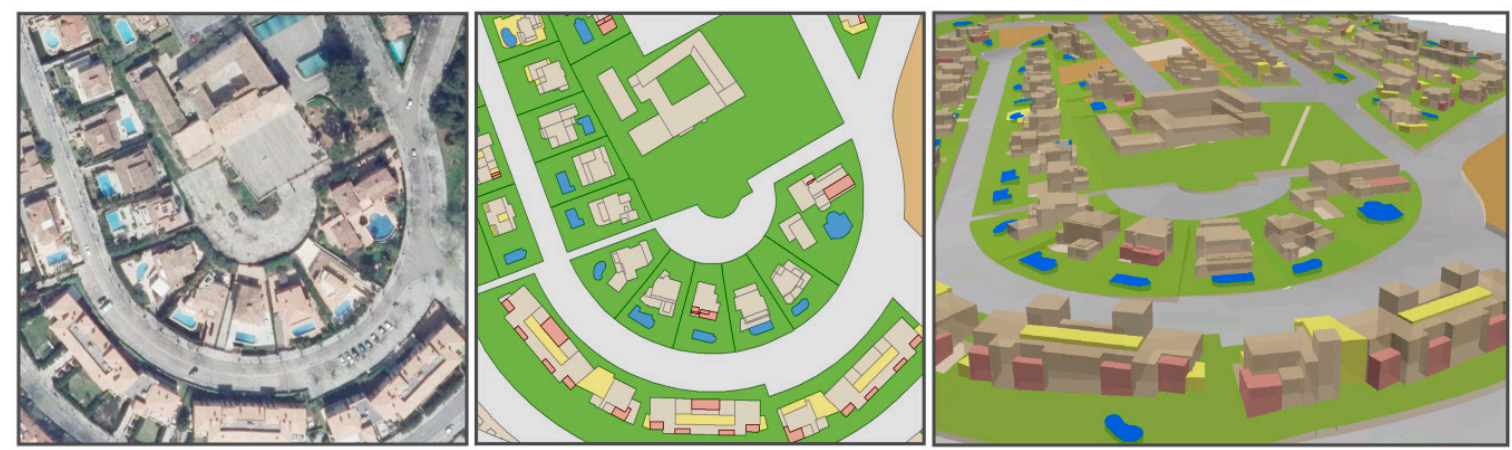

CADASTRAL CONSTRUCTION CATEGORIES

PRIVATE PARCEL $\square$ PORCH TERRACE

SWIMMING POOL __ PUBLIC GROUND

Figure 2. Orthophotography and illustration of the cadastral data used for diachronic mapping and surface measurements of swimming pools.

We obtained 67 vector files (one per municipality) from the VOC [33] and the associated tables with alphanumeric information containing-among other information —-the location, shape, size and construction year for each swimming pool entity within the Balearic Islands Cadastre $(62,599$ swimming pools in 2015). A previous calculation of the number of swimming pools [13] was based on the use of another source, the topographic map, and this is why the results differ. This information allowed us to calculate the water evaporated from swimming pools (as described in Section 2.5), but also to make separate annual estimates based on yearly swimming pool construction to reveal the evolution of evaporative water loss from swimming pools over the period 2006-2015 (Figure 2).

\subsection{Modelling Open-Water Evaporation}

The estimated evaporation $\left(E_{0}\right)$ water losses were obtained using equation (Equation (1)), proposed by Penman 1948 [29], and specifically designed to model open-water surfaces, such as lakes, ponds, or reservoirs. This equation only accounts for the atmospheric evaporative demand, regardless of water availability, which is mainly driven by incoming solar radiation, vapour pressure deficit, wind speed and air temperature. The evaporation per unit surface area $(\mathrm{mm})$ was estimated using the following equation (originally proposed by Penman 1948 [29] and later adapted to metric units by Shuttleworth (1993) [34]):

$$
E_{0}=\frac{\mathrm{m} R_{\mathrm{n}}+\gamma 6.43\left(1+0.536 \mathrm{U}_{2}\right) \delta_{\mathrm{e}}}{\lambda_{\mathrm{v}}(\mathrm{m}+\gamma)}
$$

where $E_{0}$ is the evaporation $(\mathrm{mm}), R_{\mathrm{n}}$ is the net irradiance $\left(\mathrm{MJ} \mathrm{m} \mathrm{m}^{-2}\right.$ day $\left.^{-1}\right), \mathrm{m}$ is the slope of the saturation vapor pressure curve $\left(\mathrm{kPa} \mathrm{K}^{-1}\right), \mathrm{U}_{2}$ is the wind speed $\left(\mathrm{m} \mathrm{s}^{-1}\right), \delta_{\mathrm{e}}$ is the vapor pressure deficit $(\mathrm{kPa}), \lambda_{\mathrm{V}}$ is the latent heat of vaporization $\left(\lambda_{\mathrm{v}}=2.45 \mathrm{MJ} \mathrm{Kg}{ }^{-1}\right)$ and $\gamma$ is the psychrometric constant $\left(\mathrm{kPa} \mathrm{K}^{-1}\right)$, which equals:

$$
\gamma=\frac{c_{p} P}{\varepsilon \lambda_{v}}=0.665 * 10^{-3} P
$$

where $c_{\mathrm{p}}$ is the specific heat of air at a constant pressure $\left(c_{\mathrm{p}}=1.01310^{-3} \mathrm{MJ} \mathrm{kg}^{-1}{ }^{\circ} \mathrm{C}^{-1}\right), P$ is the atmospheric pressure $(\mathrm{kPa})$ and $\varepsilon$ is the ratio of the molecular weights of water vapour and dry air $(\varepsilon=0.622)$. Calculations were performed with the function "Penman" of the $R$ package "Evapotranspiration" [35].

The different parameters in the equation were computed from basic meteorological observations, including the air temperature, atmospheric moisture, wind speed and solar radiation, as described in Allen et al. (1998) [36]. We used the daily data described in Section 2.1, and in the cases in which the wind speed, relative humidity, or global radiation were missing from more than $5 \%$ of the data 
series, we followed the recommendations by the FAO [36], which include the following: (i) For missing relative humidity data, we estimated the value of the actual vapour pressure by assuming that the dewpoint temperature was near the daily minimum temperature (Tmin). This estimate assumes that the air is nearly saturated at Tmin (relative humidity $\approx 100 \%$ ), which is especially true in the Balearic Islands due to the high levels of atmospheric moisture throughout the year. Calculating the actual vapour pressure for integration into Equation (1) is described in Allen et al. (1998) [36]. (ii) Missing solar radiation data were interpolated using data from a nearby weather station only if the physiography of the terrain was homogeneous. Stations located in the mountainous region were analysed using the Hargreaves radiation formula, which estimates the daily solar radiation based on the difference between the minimum and maximum daily temperatures (see Hargreaves and Samani (1982) [37] for details). (iii) Finally, missing wind speed data were interpolated using data from nearby stations, considering that the stations were, for the most part, governed by the same air fluxes.

Figure 3 shows a validation of the $E_{0}$ estimates using meteorological data interpolated from the Palma station versus the observed $E_{0}$ from a type-A pan evaporation located in Palma, for a random year. Equation (1) did not seem to accurately reproduce the extreme values of the $E_{0}$ (see the lower variability of the estimated versus the observed $E_{0}$ values in Figure 3, left plot). However, in general, good agreement between the estimates and the observations was obtained (Figure 3, right plot), with a Pearson correlation of $R=0.87$. The monthly and annual sums of the estimated $E_{0}$ were very similar to the observed $E_{0}$ values (overestimate $\approx 5 \%$ ).
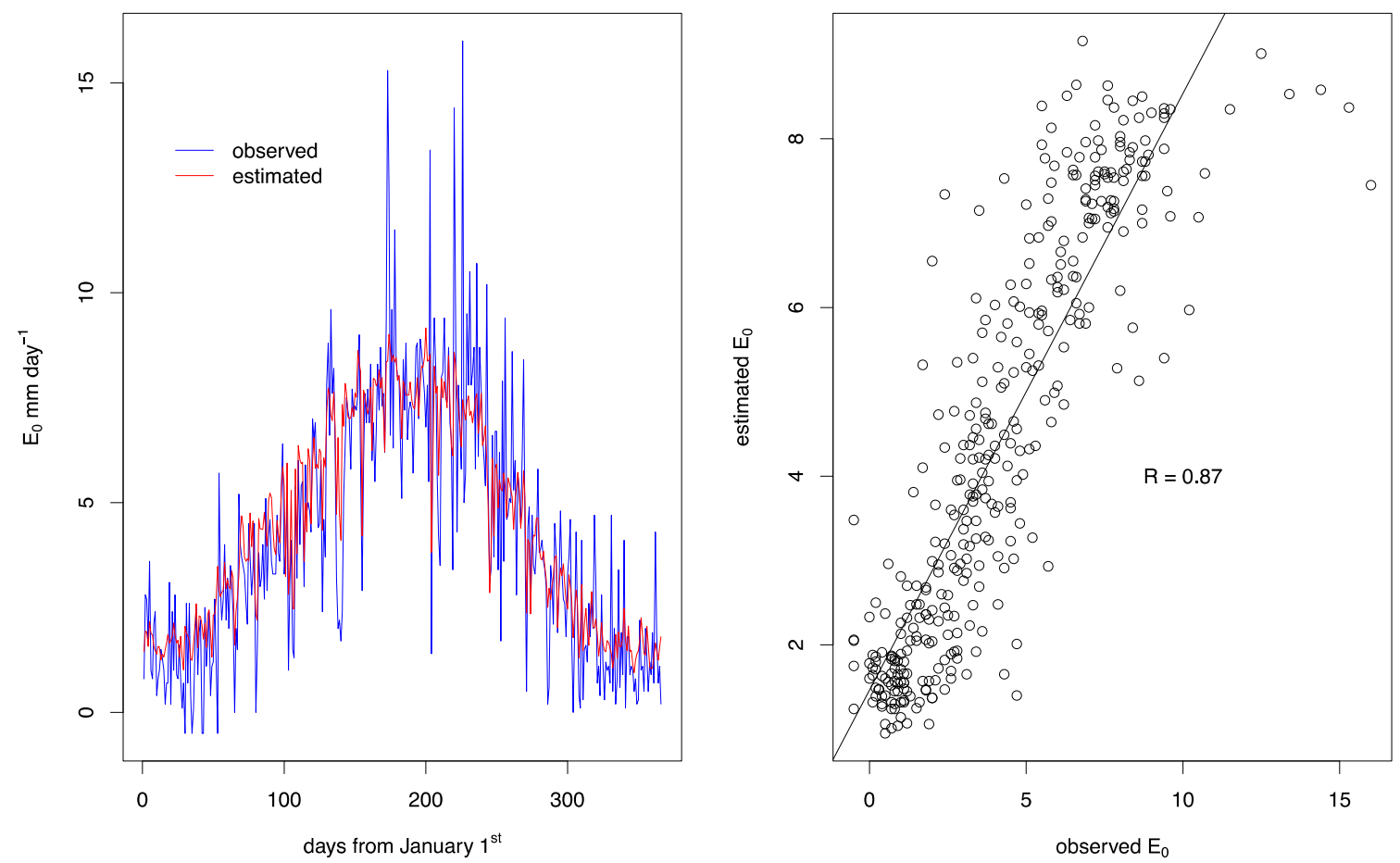

Figure 3. Estimated versus observed evaporation $\left(E_{0}\right)$ in Palma for 2008.

We computed the daily $E_{0}$ at 16 locations across the islands for the period 2006-2015. The monthly sums for each year and the monthly averages over the entire period were then calculated. This allowed us to generate 12 maps of the monthly evaporation for the islands based on an ordinary co-kriging interpolation using the elevation (100 m resolution) as a co-predictor [38]. The map overview shows a typical seasonal distribution of $E_{0}$ in Mediterranean environments. The summer months provided evaporation sums with values up to $200 \mathrm{~mm} /$ month in July, and winter registered low values of $E_{0}$ due to the lower temperature and higher relative humidity (Figure 4). The following spatial pattern was generally repeated throughout the year: lower $E_{0}$ values were observed at the summits of the Tramuntana mountain range (N-NW of the Mallorca island), and increasing $E_{0}$ values were observed 
toward the central and southern regions of the islands, where elevations were generally $<200 \mathrm{~m}$ a.s.1. Together with the spatio-temporal precipitation patterns, these characteristics were the climatic drivers of water scarcity in the Balearic Islands, that is, low precipitation values during the summer months and in the lowlands, and higher precipitation in the winter in the mountainous areas. This is critical for understanding and interpreting the results of this paper, as it is precisely the central and southern regions of the islands where most swimming pools are concentrated (Figure 1). Additionally, the summer months feature a higher water demand associated with tourism (including evaporation from swimming pools) and a lower water availability in atmospheric terms.

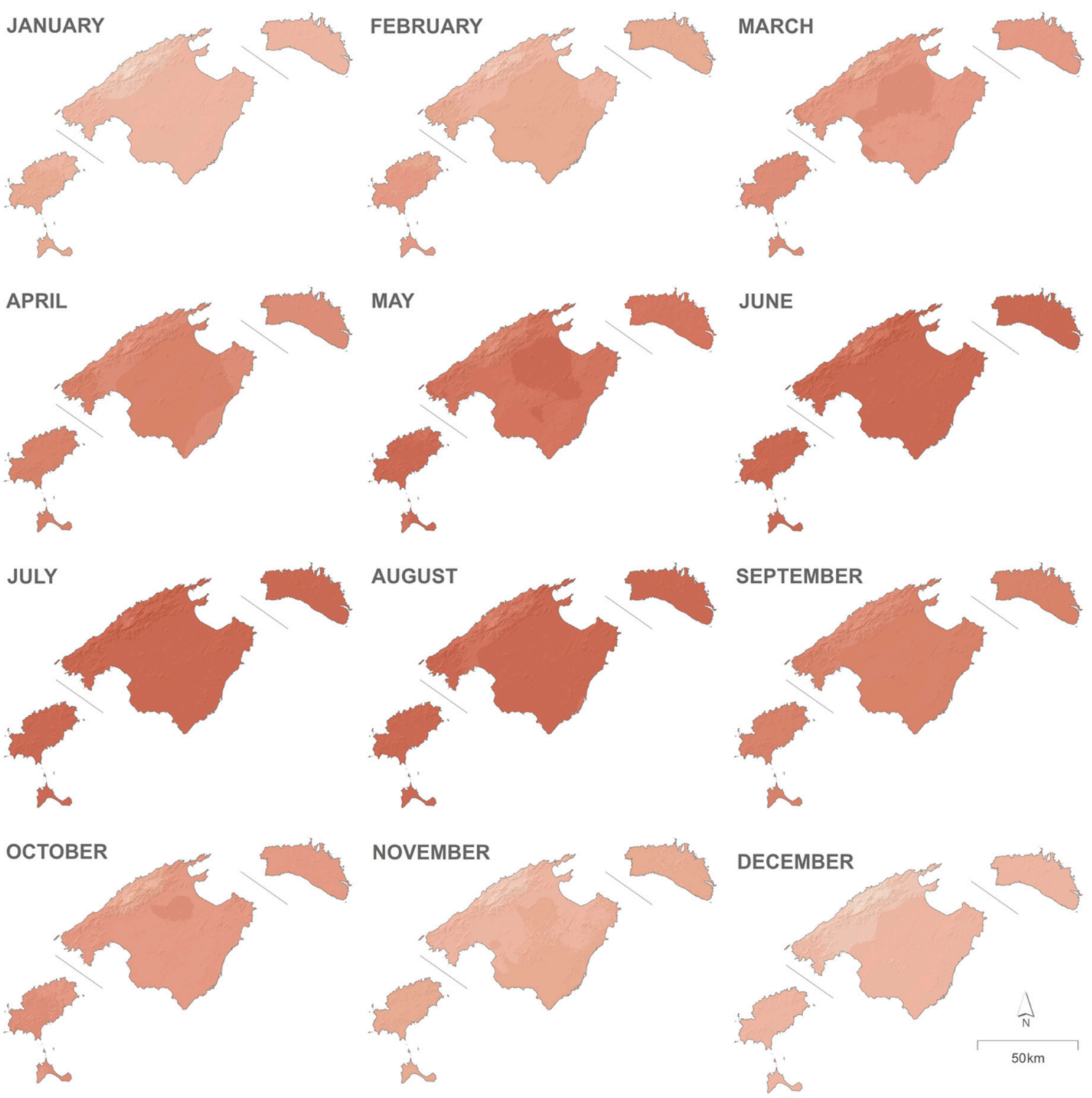

Open water evaporation (liters $/ \mathrm{m}^{2}$ )

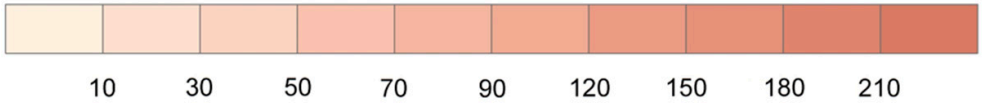

Figure 4. Spatial distribution of the interpolated monthly open water evaporation in the Balearic Islands (2006-2015 average). 


\subsection{Calculating the Water Volumes Evaporated from Swimming Pools}

The interpolated maps and cadastral spatial information were used to calculate the water evaporated at each swimming pool according to the following procedure: first, we selected swimming pool entities within the spatial data supplied by the VOC and calculated the area of each swimming pool based on its georeferenced graphical representation. We extracted the values $\left(\mathrm{L} \mathrm{m}^{-2}\right)$ of each of the 12 monthly evaporation matrices and added them onto each swimming pool entity. Finally, we obtained the evaporated water volume at each swimming pool by multiplying the swimming pool area $\left(\mathrm{m}^{2}\right)$ and the interpolated evaporation at each point $\left(\mathrm{L} \mathrm{m}^{-2}\right)$. Separately, the values at the point locations $(62,599$ swimming pools) were summed up by municipality for subsequent analysis. A kernel density function was applied to the swimming pools layer (volume of water evaporated at each swimming pool) to extract the spatial patterns of water evaporated from the swimming pools.

\subsection{Shaded Pool Correction of the Evaporation Estimates}

Evaporation modelled using the Penman equation applied to places with no shelter or shade. This is a basic assumption of the model, as the input meteorological data were assumed to be measured at a standard meteorological station. However, many swimming pools are located amidst hotel buildings or adjacent to house walls. Therefore, there must be some hours during the day in which the pools are shaded, thereby receiving less radiation, which decreases evaporation. This factor was considered in our evaporation estimates by implementing a shade model developed using standard GIS software applied to two locations in Palma de Mallorca and Ibiza (where the measured solar radiation data were available) near the meteorological stations from which we obtained the data. This model computed the theoretical radiation that the pool received throughout the year considering a detailed digital elevation model derived from the cadastral information (i.e., number of floors; Figures 2 and 5). The modelled radiation was compared with the observed radiation, and the mean difference was computed. This value was then subtracted from the series of observed radiation, and the Penman model (Equation (1)) was run again using these corrected series. The new evaporation estimates were lower than the original values at the two test locations, and the results are shown in Section 3.4.

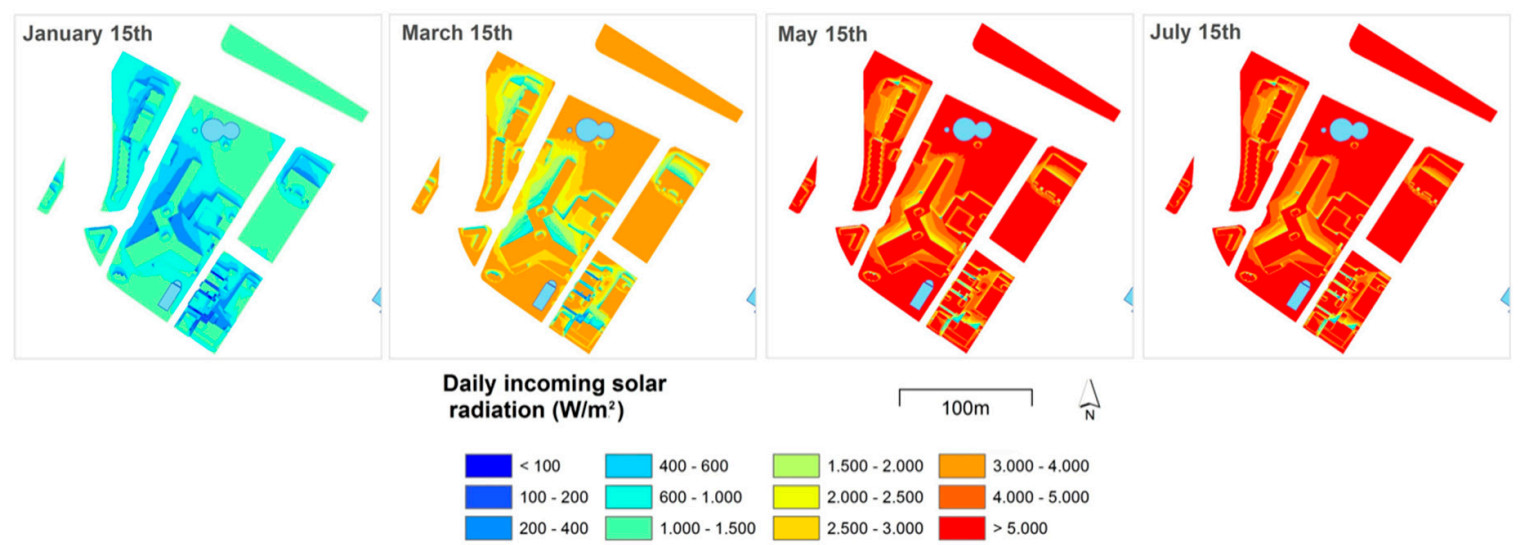

Figure 5. Details of the daily incoming solar radiation model used to correct the theoretical radiation.

\section{Results and Discussion}

\subsection{Temporal Pattern of Swimming Pool Proliferation}

A diachronic analysis of the cadastral data on swimming pools revealed a decrease in the pool area constructed on the islands per year since 2009, most likely as a consequence of the financial and economic crisis of 2008. However, in cumulative terms, a steady increase in the swimming pool total surface area and number between 2006 and 2015 is evident (Figure 6). 


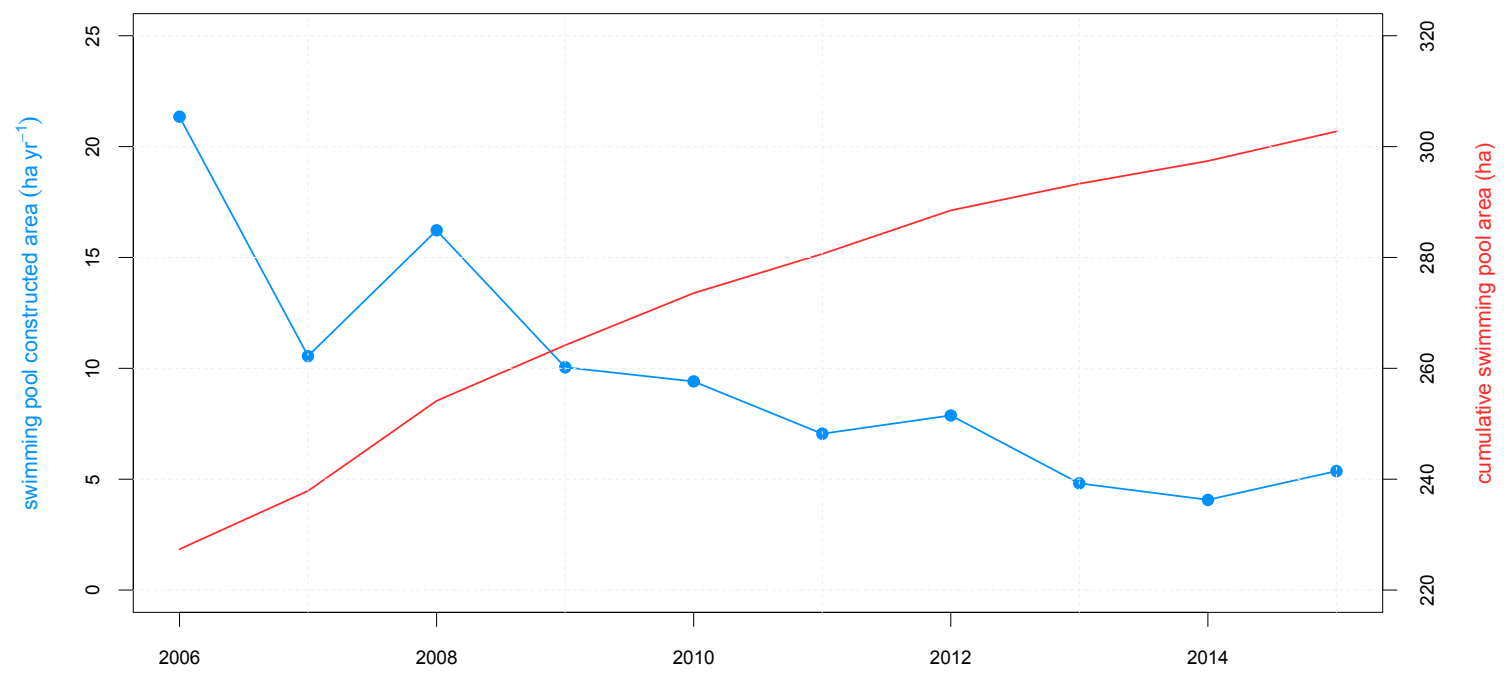

Figure 6. Evolution of swimming pool surface area in the Balearic Islands over a decade (2006 to 2015).

The number of swimming pools increased by $47.4 \%$ at a mean annual growth rate of $3.3 \%$, whereas the pool surface area increased on average by 3.9\%, reaching more than 300 hectares in 2015 . Results from our cadastre analysis showed that hotel swimming pools represented no more than $5 \%$ of the 62,599 swimming pools in the Balearic Islands (2015). In 2012, there were 0.05 swimming pools per capita, and 2577.3 square metres of outdoor swimming pool water surface per 1000 inhabitants. By comparison, in Germany, an average water surface area of 64.1 square meters was available per 1000 inhabitants, according to sports facility statistics of all 6716 outdoor and indoor swimming pools in Germany [39].

\subsection{Evaporative Water Loss from Swimming Pools}

Figure 7 shows the spatial pattern associated with swimming pool evaporative losses on monthly and annual bases. July and December represented the maximum and minimum evaporative monthly sums. The maps merge the Balearic climatology (atmospheric water demand) and swimming pool density. In relative terms, Ibiza Island, with the highest spatial density of pools, displayed the highest swimming pool evaporation value. In Mallorca, evaporation was spatially concentrated in those areas in which pool density and $E_{0}$ were higher: (1) the urban areas of Palma Bay (W), Pollença and Alcudia Bays (NE) and the corridor between them (Palma-Alcudia highway); and (2) on the eastern coast, where touristic ports and high-standard second homes proliferate. The water loss from swimming pools in these areas may reach nearly 4 million $\mathrm{L} \mathrm{km}^{-2}$ annually, assuming that no pool covers are used. The average evaporation rate is 4.4. $\mathrm{L} \mathrm{m}^{-2}$ per day. Estimates of the pan-evaporation rates in the desert climate of Phoenix, Arizona are $5.2 \mathrm{~L} \mathrm{~m}^{-2}$ per day, and a typical uncovered swimming pool with around $60,000 \mathrm{~L}$ loses approximately 2 meters of water a year to evaporation, which is $132 \%$ of the average pool filling capacity [21]. 


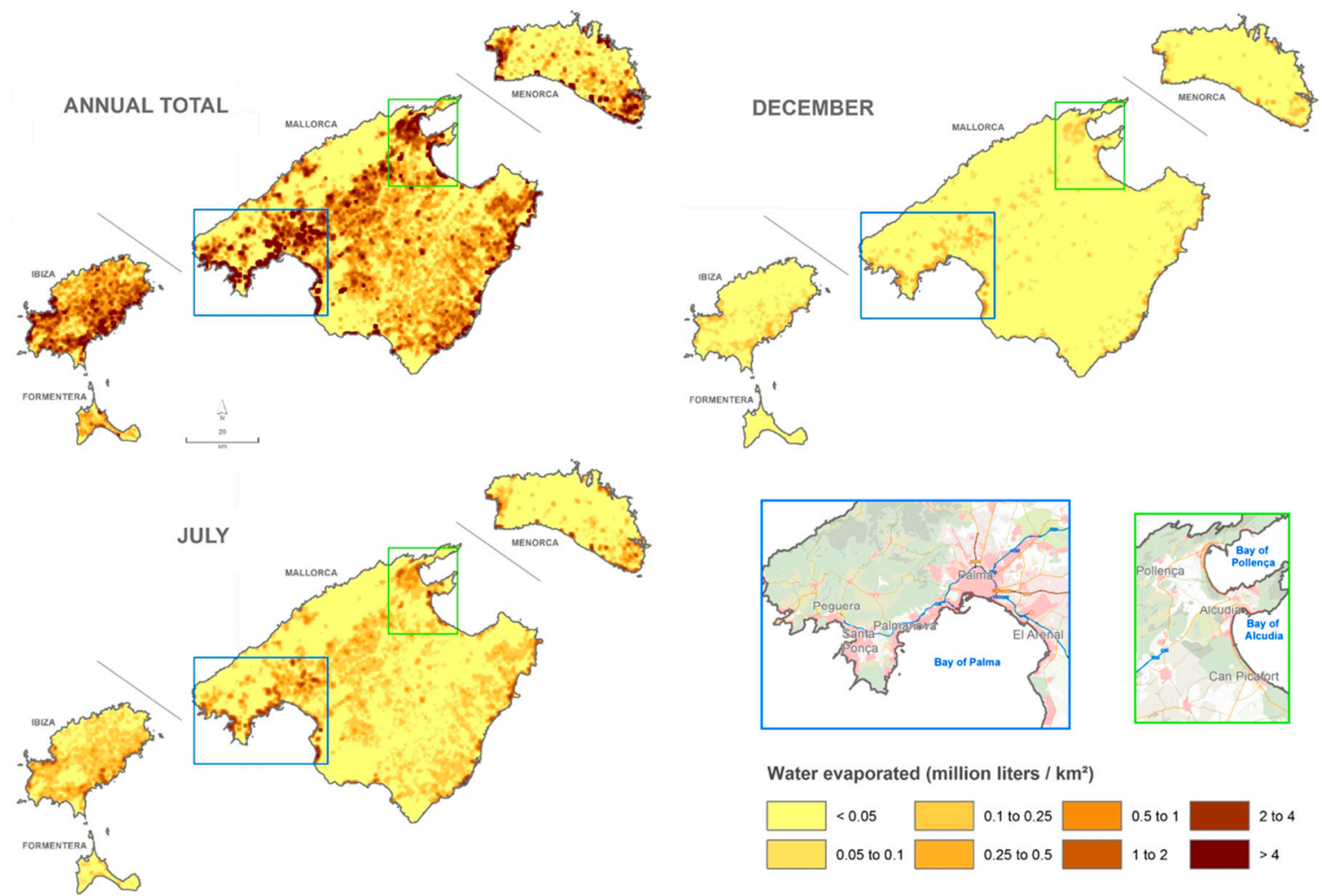

Figure 7. Spatial pattern of the water volumes evaporated from swimming pools in the Balearic Islands (2006-2015 average): annual (top left), July (annual max., bottom left) and December (annual min., top right).

A summary of pool evaporation by island is shown in Table 1 (data by municipality and year is available, but not shown). In absolute terms, Mallorca, the largest island, accounted for the largest amount of water loss by evaporation, with nearly 3278 million L $\left(3.3 \mathrm{hm}^{3}\right)$ in 2015 , and a $31 \%$ increase relative to 2006. In relative terms (per island area), Ibiza showed the largest ratio of evaporative losses, with 1.44 million $\mathrm{L}$ per $\mathrm{km}^{2}$ in 2015 , and a per cent change of $+45 \%$ relative to 2006 . In total, 4818 million litres $\left(4.8 \mathrm{hm}^{3}\right)$ were lost from swimming pools in the Balearic Islands in 2015 , with a $31 \%$ increase compared to 2006. The water evaporated annually from swimming pools was the equivalent of 80,971 pool fill volumes, assuming swimming pools that typically measure $38 \mathrm{~m}^{2}$ with a depth of $1.5 \mathrm{~m}$ (estimated in reference to Vidal et al. (2011) [23]) and a resulting filling capacity of 57,700 L (Figure 7). Considering the total 62,599 swimming pools in the archipelago, the water needed for pool re-filling is equivalent to 1.2 pools per year.

Table 1. Evaporative water loss from swimming pools in the Balearic Islands (million L).

\begin{tabular}{cccccc}
\hline Island & $\mathbf{2 0 0 6}$ & 2006 Relative to Size $\left.\mathbf{( k m}^{\mathbf{2}}\right)$ & $\mathbf{2 0 1 5}$ & 2015 Relative to Size $\mathbf{( \mathbf { k m } ^ { 2 } )}$ & 2006-2015 Variation $(\mathbf{\%})$ \\
\hline Formentera & - & - & 30.2 & 0.36 & - \\
Ibiza & 565.4 & 0.99 & 822.6 & 1.44 & 45.5 \\
Mallorca & 2478.3 & 0.68 & 3278.6 & 0.90 & 32.3 \\
Menorca & 579.7 & 0.83 & 686.6 & 0.98 & 18.4 \\
Total & $\mathbf{3 6 5 3 . 6}$ & $\mathbf{0 . 7 4}$ & $\mathbf{4 8 1 8 . 0 7}$ & $\mathbf{0 . 9 8}$ & $\mathbf{3 1 . 9}$ \\
\hline
\end{tabular}

It is instructive to compare the above figures to the reservoir capacity on Mallorca Island. Although the largest freshwater resources in Mallorca are stored in rock aquifers $(\approx 85 \%)$, two reservoirs were built in the 1970s to ensure water for urban and agriculture supply. They have capacities of 7.3 and $4.6 \mathrm{hm}^{3}$, accounting for nearly $4 \%$ of the water resources of the island [9]. At the moment of acquisition of data for this research (autumn 2017), Spain and the Balearic Islands were in the middle of a severe hydrological drought, and these reservoirs barely reached $40 \%$ of their capacity, accounting for a 
combined storage of $4.4 \mathrm{hm}^{3}$ [40]. The water lost by evaporation from swimming pools in Mallorca per year may thus represent one-third of the storage capacity of these reservoirs. During years of water scarcity, the evaporation amounts may equal the actual water stored in reservoirs. This is just an example that highlights the need to raise awareness of freshwater waste on the islands and to implement water-saving measures, as we will discuss later.

Note that the above figures describing the increase in evaporative water loss from swimming pools only reflect the increased number of swimming pools constructed between 2006 and 2015 (Figure 6). We did not consider any patterns or trends in the atmospheric evaporative demand during that period. The evaporation maps (Figure 7) only represent the average for the 2006-2015 period, but it is evident that inter-annual evaporation variations must exist. Figure 8 shows that the observed evaporation in Palma over the time span of this work (2006-2015) displayed typical inter-annual variability, but no apparent trend was observed. Longer time periods over which observed evaporation data are available reveal an increasing evaporation trend at a rate of $+12.6 \mathrm{~mm}$ per year over the last 25 years. This agrees with the general trend observed for Spain [41], and is mainly due to increasing atmospheric temperatures and the subsequent decrease in relative humidity in the context of global warming. The trends in Palma are representative of the trends observed in the insular territories: over short time-scales, an increase in the swimming pool evaporative losses resulted from an increase in the number of existing pools, but over longer periods, the increasing atmospheric water demand must be considered. In this sense, climate projections do not augur a promising future. By the end of this century, temperatures in the Mediterranean are projected to rise between 2 and $4{ }^{\circ} \mathrm{C}$, depending on the greenhouse gas scenario considered [42,43], and this effect will enhance the atmospheric water demand. Climate models project increasing anticyclonic circulation over the Mediterranean with a northward shift in the mid-latitude storm tracks leading to a decrease in precipitation by $20 \%-30 \%$ [42] and more frequent and severe drought episodes [44] that are expected to aggravate the existing pressure on water resources in this environment. Swimming pools create a water "lock-in" on the urban water supply in the Balearics by increasing demand for water through outdoor residential amenities (see Section 1.1).

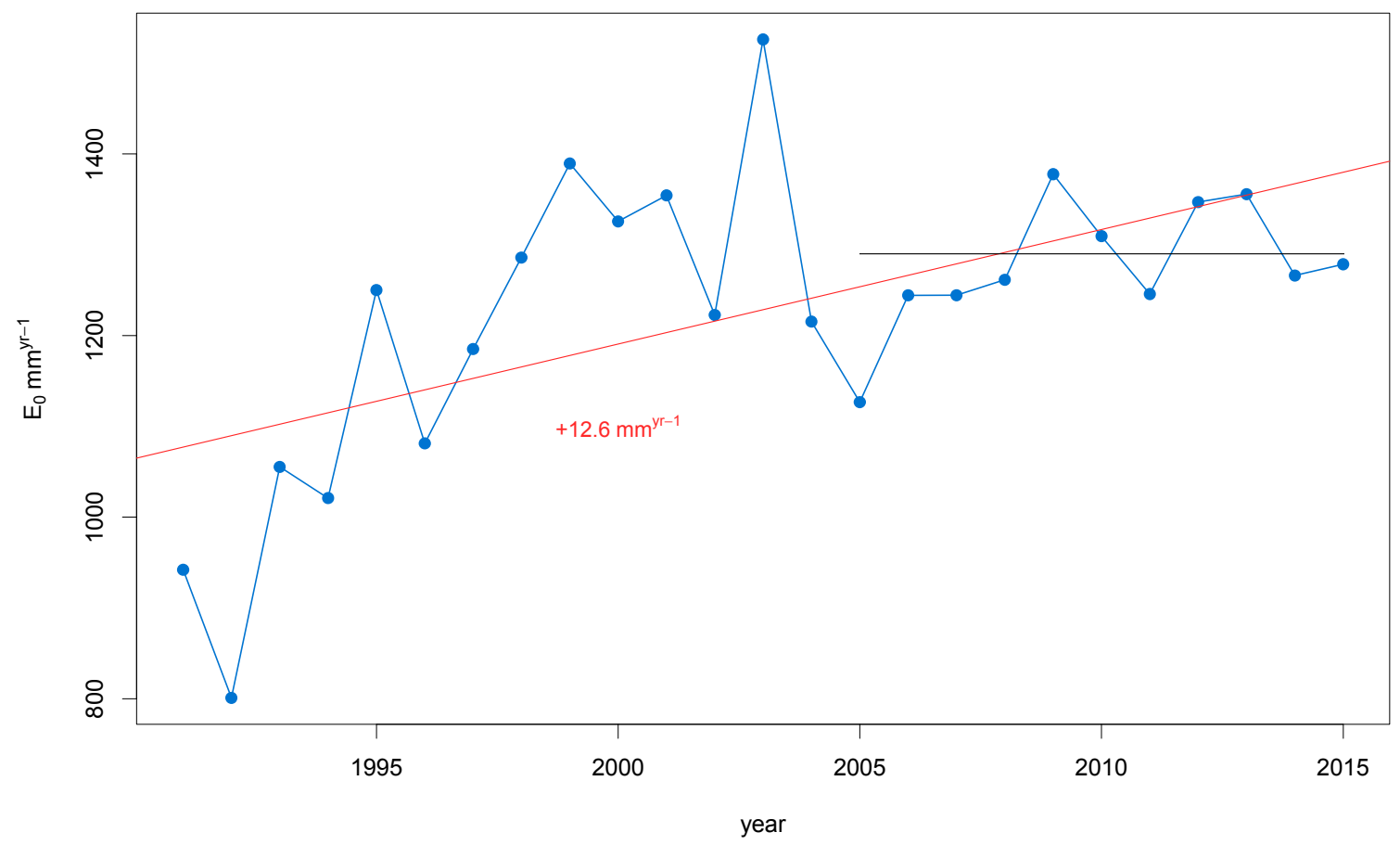

Figure 8. Evolution of the yearly sums of the observed evaporation in Palma (Mallorca) over the period 1991-2015. The trend lines (linear regressions) are fitted to the 1991-2015 (red) and the 2006-2015 sub-period (black) observed $E_{0}$ data, respectively. 


\subsection{The Role of Swimming Pools in Tourist and Residential Urban Water Budgets}

Water supply and consumption data do not discriminate between the tourism and the residential urban sectors. Municipalities and water providers supply both sectors, and the aggregate data obtained from the residential and dynamic tourist populations are used to determine the urban water demand in the hydrological plans [25]. Water use for tourism and its different sub-sectors (i.e., hotels, second homes, facilities, activities, etc.) eludes statistical observation $[15,45]$. The most widely used indicator of water consumption in tourism, litre per guest night, must be combined with the population water consumption per person night.

The results of our analysis revealed that evaporation from swimming pools added $9.6 \mathrm{~L}$ of water consumption per guest night and person night in the Balearic Islands (Table 2). Evaporative water loss by swimming pools represented $4.9 \%$ of urban potable water consumption and $3.6 \%$ of urban potable water supply estimates in the Balearic Islands, respectively. In Mallorca, these values were $4.4 \%$ and $3.2 \%$ of urban potable water consumption and supply estimates, respectively. Swimming pool water use ranged from 8.5 to $15.7 \mathrm{~L}$ per guest night and person night, indicating pronounced inter-island differences in swimming pool surface availability to both residents and tourists (Table 2). The size class distribution characterized the relatively high percentage of swimming pools connected to individual houses rather than to official tourist accommodations in Mallorca (Figure 1; Table 2).

Table 2. Swimming pool water use indicators for the year 2015. Data source: swimming pool inventory, evaporation calculations and data from Govern de les Illes Balears (2017, 2016); IBESTAT (2017a, 2017b).

\begin{tabular}{|c|c|c|c|c|}
\hline & Balearic Islands & Mallorca & Menorca & Ibiza + Formentera \\
\hline Number of municipalities & 67 & 53 & 8 & Ibiza: 5, Formentera: 1 \\
\hline Person nights [Millions.] & 403.1 & 313.6 & 33.7 & 55.8 \\
\hline Guest nights [Millions.] & 101.2 & 71.5 & 10.1 & 19.6 \\
\hline Swimming pools in 2006 & 46733 & 32340 & 7809 & 6624 \\
\hline Swimming pools in 2015 & 62599 & 43697 & 9252 & 9650 \\
\hline $\begin{array}{l}\text { Swimming pool water use [L per guest night } \\
\text { and person night] }\end{array}$ & 9.6 & 8.5 & 15.7 & 11.3 \\
\hline $\begin{array}{l}\text { Mean municipal swimming pool water use } \\
\text { increase } 2006-2015 \text { in } \% \text { (standard deviation) } \\
\text { and coefficient of variation (cv \%) }\end{array}$ & $\begin{array}{c}40.1 \\
(28.1) \\
\mathrm{CV} 69.6 \%\end{array}$ & $\begin{array}{c}44.3 \\
(29.1) \\
\operatorname{cv} 65.6 \%\end{array}$ & $\begin{array}{c}15.6 \\
(3.3) \\
\mathrm{cV} 21.3 \%\end{array}$ & $\begin{array}{l}38.5 \\
(21.6) \\
\text { cv } 56.2 \% \\
\text { (Ibiza) }\end{array}$ \\
\hline $\begin{array}{l}\text { Official estimates of water supply [L per guest } \\
\text { nights and person nights] }\end{array}$ & 263.2 & 262.8 & 265.1 & 264.2 \\
\hline $\begin{array}{l}\text { Water use by swimming pools as mean } \\
\text { percentage of official water supply estimates } \\
\text { per municipality (standard deviation) }\end{array}$ & $6.6(4.2)$ & $6.8(4.3)$ & $6.1(2.1)$ & $\begin{array}{c}3.9 \\
(5.2)(\text { Ibiza }) \\
4.7 \text { (Formentera) }\end{array}$ \\
\hline
\end{tabular}

The highest increase occurred in Menorca Island, and the variability between municipalities was most pronounced here as well (Table 1, data by municipality and year is available in supplementary material Table S1). Overall, different municipalities exhibited different patterns of change. This is a subject for further research.

Among the 67 Balearic Island municipalities over the years 2000 to 2015, official estimates of the aggregate annual water supply and consumption in the urban residential and tourist sectors are available [46]. Calculating the indicator of litres of water supply per guest night and person night using these data revealed that on average, $263.8 \mathrm{~L}$ of water per person per day were consumed at the municipal level (Table 2). Comparing swimming pool water use indicators between municipalities demonstrated that aggregated estimates of water consumption failed to acknowledge that an increasing number of residents and some housing typologies (especially high-income residential houses) translated into locally and seasonally exceptionally high pressure on water resources (Table 2). 


\subsection{Corrected Estimates of Water Use by Swimming Pools That Received Less Radiation Due to Shading During Some Hours of the Day}

The results described so far do not account for shading. Pools located between the buildings of hotels or near house walls receive reduced quantities of radiation, which translates into a lower quantity of water lost to evaporation. Table 3 lists the differences in $E_{0}$ estimated using the measured radiation and radiation corrected with a coefficient derived from the shade model described in Section 2.5. In the summer months, when the absolute effects of the shade on the total received radiation were higher, the $E_{0}$ could be reduced by $20 \mathrm{~L} \mathrm{~m}^{-2}$ per month. Annually, the quantity of estimated $E_{0}$ was reduced by about $160 \mathrm{~L} \mathrm{~m}^{-2}, 8 \%$ of the $E_{0}$ estimates without radiation correction. These values represent estimates at just two locations in hotel complexes in Palma and Ibiza, considering the particular building morphology, orientation and shade configuration. Given the huge computational effort required for the daily shade models, we could not reproduce the same analysis over the tens of thousands of swimming pools in the islands, but we assumed that corrected $E_{0}$ values associated with shaded swimming pools were always around 5\%-10\% lower than those associated with shade-free locations. We do not exactly know how many swimming pools in the islands are under the influence of shading, and must consider these corrections merely as illustrative. Other factors might counteract the effects of shading, and could increase the water lost from swimming pools, including water splashing or the existence of leaks in the filter systems [14]. These aspects are far beyond the scope of this paper. Moreover, we did not consider water loss due to the evaporation of indoor pools in the archipelago. Existing literature elucidates models for estimating indoor pool evaporation $[47,48]$. However, data vital and well-suited to our approach (i.e., indoor pool surface and indoor meteorological conditions) do not exist. In addition, the total number of indoor swimming pools in the islands is very low. According to tourism platform Trip Advisor [49], only 149 out of 1877 hotels listed for Mallorca (0.08\%) feature an indoor swimming pool. Furthermore, indoor conditions such as high relative humidity and lack of wind and solar radiation result in lower water evaporation rates. Therefore, we conclude that the amount of water loss from indoor swimming pools, compared to that of outdoors pools, is negligible for the purpose of the present study.

Table 3. Evaporation calculations corrected for decreased radiation received by swimming pools due to shading during some hours of the day. Units: $\mathrm{L} \mathrm{m}^{-2}$.

\begin{tabular}{|c|c|c|c|c|c|c|}
\hline & Palma & Palma Corrected & Difference & Ibiza & Ibiza Corrected & Difference \\
\hline January & 61.1 & 57.0 & 4.0 & 73.5 & 69.2 & 4.3 \\
\hline February & 78.3 & 71.1 & 7.3 & 95.3 & 87.4 & 7.9 \\
\hline March & 127.2 & 115.1 & 12.1 & 141.8 & 128.8 & 13.0 \\
\hline April & 162.5 & 147.5 & 15.0 & 169.8 & 153.7 & 16.1 \\
\hline May & 216.9 & 199.1 & 17.9 & 211.8 & 192.8 & 19.0 \\
\hline June & 253.4 & 234.1 & 19.2 & 242.4 & 222.0 & 20.5 \\
\hline July & 277.4 & 256.3 & 21.1 & 262.2 & 239.4 & 22.8 \\
\hline August & 240.1 & 219.7 & 20.3 & 232.4 & 210.1 & 22.3 \\
\hline September & 169.7 & 152.7 & 17.0 & 173.2 & 154.8 & 18.4 \\
\hline October & 117.4 & 104.5 & 12.8 & 123.2 & 109.1 & 14.0 \\
\hline November & 72.9 & 66.8 & 6.1 & 85.7 & 79.1 & 6.6 \\
\hline December & 55.9 & 53.5 & 2.4 & 63.5 & 60.7 & 2.8 \\
\hline TOTAL $\left(\mathrm{L} \mathrm{m}^{-2}\right)$ & 1832.7 & 1677.5 & 155.2 & 1874.7 & 1707.1 & 167.6 \\
\hline
\end{tabular}

3.5. Swimming Pools Water Use in the Context of Water Resource Management and Policy Implications of the Results

This analysis estimates the water volumes used by swimming pools and gives valuable insight into the climate sensitivity of this water consumption, which is driven by temperature, precipitation and evaporation [21]. We addressed evaporation, which is difficult to assess as it depends on the pool water surface and climatic drivers such as air temperature, humidity, wind speed and solar radiation. Moreover, evaporative water loss is a proxy for re-filling pools on a daily basis [14]. 
This is an important contribution to the literature on outdoor water use in the form of swimming pools, because detailed evaporation studies of small water reservoirs like swimming pools are scarce. One reason for this scarcity is that pan-evaporation data are not available in many parts of the world, posing methodological challenges and imposing high technological and cost demands on in-field measurements. For example, Molina Martínez et al. (2006) [50] collected hourly averaged Class A pan data to develop a model for pan evaporation estimates from meteorological data in Spain. Gallego-Elvira et al. (2010) [51] surveyed agricultural water reservoirs for one year to develop an energy balance assessment and to derive evaporation losses in the semi-arid south-eastern region of Spain. The methodological approach demonstrated here revealed that estimates of evaporation loss can be combined with swimming pool inventories from cadastres, geodatabases, or orthophotography-derived maps to obtain the average water consumption figures for swimming pools over large spatial units. As in most studies of water use in swimming pools, our analysis failed to assess two other important aspects of pool water consumption: we did not account for initial filling of the pool or the cleaning of pool filters [14]. As these water volumes depend on the swimming pool numbers and evaporative water losses, the results obtained here are expected to differ from actual values, but the general trends should be conserved.

Comparing evaporative water loss to urban water consumption levels translates the water loss from swimming pools into temporal and spatial units that are informative and meaningful for policymakers and practitioners. For example, our results show that evaporation in winter months, when swimming pools are not used (November through March), represents 20\%-25\% of yearly evaporation. This can bring insights into the potential water savings obtainable by introducing the mandatory use of pool covers during such months. Pool covers are just one example of mandatory measures of water saving that could be implemented in the Balearic Islands. However, public debate in the Balearic Islands should go beyond the use of technological approaches for future water conservation. The Balearic debate could learn from the experiences that other localities with limited water resources (e.g., southwestern USA) have made with water conservation measures in comparable urban contexts. Specifically, these are areas where a sizable portion of urban water is used for outdoor purposes, where water prices are low, and where climate risk is just entering the public policy agenda. In a case study on the city of Los Angeles, Mini et al. [49] showed that the effectiveness of voluntary water restrictions was low. The objective of lowering residential water use was reached through a combination of pricing measures and mandatory water use restrictions. Such water conservation measures had the greatest impact on high water users in residential areas. Ninety-five percent of outdoor swimming pools in the Balearic Islands are connected to individual houses, and the private use of swimming pools is dominant in the Balearic Islands today. Thus, targeting households with higher water consumption could be an effective means of lowering residential water use.

In addition to providing insight into potential water savings, our results on swimming pool water use can inform the design of water tariffs to more effectively target high outdoor water use $[25,49,50]$. For Mallorca, Deyà-Tortella et al. [25] argue that policymakers should consider household typology and the price elasticity of demand by residential households for water. Their analysis in Mallorca suggested that a tariff scheme that differentiated between houses with or without a swimming pool, lawn, or other housing characteristics could be fairer than the current water pricing structure. A policy that simply increased water prices could particularly affect families with lower incomes who already consume less water $[25,48,49,52]$. Based on an analysis of domestic water prices in all Mallorcan municipalities, and in agreement with other studies [16,18,25], Hof et al. [50] showed that particularly in cases where housing types with high-income residential houses with lawns and swimming pools dominate, the block rate is not sufficiently progressive and water prices are too low. In fact, the water pricing structure is so distorted that water costs for hotels are extremely low [51]. Deyà-Tortella et al. [51] revealed the low share of water costs with respect to the total hotel operational costs and concluded that the introduction of water-saving initiatives constitutes an effective way to reduce consumption. Hence, 
water conservation measures in the hotel and tourism sector in the Balearic Islands are expandable and could make a sizable contribution to water conservation [51].

Water resources management in the Balearic Islands is complex, and we do not intend to propose a quick technological fix such as pool covers to reduce total urban water consumption. Instead, we add quantitative information on the most significant water-consuming factors in urban landscapes across the Balearic Islands today. The quality tourism model is linked to the expansion of a spacious residential matrix characterized by large plots, irrigated lawns and swimming pools. However, territorial and tourism planning, with a long tradition in the Balearic Islands, has involved the restriction of new urban development, tourist accommodation supply, new golf courses, or new villas in the countryside $[10,13,28]$. The implementation of these types of preventive measures could also involve setting an upper limit on the number of new swimming pools being constructed in order to ensure a more sustainable use of water in the islands.

In their analysis of the effects of water price reforms on water consumption in Mallorca, Deyà-Tortella et al. [25] concluded that policymakers should consider household typology and the income effects of price reforms. Swimming pool proliferation over just one decade (2006-2015) and the swimming pool density distribution provide important insights into this recent urban and tourist transformation in the Balearic Islands. Relating land use changes to real estate development, investment and residential tourism in Mallorca, Hof and Blázquez-Salom [13] reported a steady increase in buildings located in the countryside, with 40,567 swimming pools being constructed in Mallorca by 2006 , with $46 \%$ of them located outside of the designated urban areas. Previous analyses of a land use inventory database and an orthophotography interpretation of Mallorca revealed that the average pool size in single residential houses $(n=961)$ ranged from $26.5 \mathrm{~m}^{2}$ (standard deviation $12.7 \mathrm{~m}^{2}$ ) in densely built-up areas to $37.7 \mathrm{~m}^{2}$ (standard deviation $21.7 \mathrm{~m}^{2}$ ) in low-density areas with a more spacious residential matrix and larger plots (compare Hof and Schmitt (2011) [28]). Morote et al. (2017) [12] reported that on average, single-family pools measured $39.7 \mathrm{~m}^{2}$ and community pools measured $112.7 \mathrm{~m}^{2}$. The frequency distribution of swimming pools (Figure 1) indicated that smaller pools connected to individual houses for private use currently dominate the Balearic Islands.

Of course, water conservation measures in the agricultural sector and the hotel-based mass tourism water demand sector over the Balearic Islands could drastically reduce the total water consumption in the archipelago. The Balearic Islands are facing water resources problems that are linked with and at the same time rooted in dependency on tourism as the islands' main industry. No single water conservation strategy will be adequate in itself, but must consider the interdependencies and complexities of water and tourism, urban form and water consumption, and price mechanisms across private households, tourist business and agriculture. In this context, we argue that the first priority is to highlight and reveal the water consumption that is related to the latest tourism development trend in the Balearic Islands and the whole Mediterranean coast, namely the proliferation of irrigated lawns and swimming pools. Next, the effectiveness of water conservation measures in various water demand sectors can be discussed, taking into consideration the experiences and lessons learnt in contexts where water conservation analysis and policy is more advanced (compare [16,49]).

A more realistic, effective and sustainable solution can only lie in a holistic water resources management. This has to include a reconsideration of the shift in the Balearic tourism model along the residential tourism trajectory. Extending and complementing the consolidated mass tourist business, residential tourism contributes to the increasing commodification of dwellings for holiday rentals and stimulates an accelerated tourist demand [13]. These developments reinforce the water resources problems that have been discussed elsewhere $[6,10,12,16]$. Our tentative examples for water saving potentials are to be seen in this wider framework. We hope to alert the Balearic Islands' population to the existence of the water resources problems and climate risk-for example, by showing that yearly sums of swimming pool consumptive water use can account for one-third or half of the water storage capacity of the two reservoirs located in the Tramuntana mountain range. In the Balearic context, 
raising awareness and providing facts and numbers on the different water demand sectors is the first step to moving towards more advanced water conservation analysis and policy.

\section{Conclusions and Outlook}

Our work focused on water loss from swimming pools by evaporation in the highly touristic Balearic Islands over the last decade (2006-2015). Although we observed a trend toward fewer swimming pools constructed per year, in cumulative terms, the number of swimming pools has clearly increased, from 46,773 in 2006 to 62,599 in 2015 . Only $5 \%$ of the pools are in hotels, while the remainder complements the offer of residential and holiday homes, increasingly commercialized for tourist rental. This change in the tourist model is in the public debate, which our results aim to enrich.

Open-water evaporation estimates in the archipelago can potentially reach $1800 \mathrm{~mm}$ per year, with summer months accounting for more than half of the annual values. When merging these values with the actual swimming pool area in the islands, we obtained estimates of the actual water losses from swimming pools due to evaporation. In 2015, almost $5 \mathrm{hm}^{3}$ were lost from swimming pools across the entire territory, with $70 \%$ of evaporation occurring on Mallorca Island. In relative terms, Ibiza has the largest number of swimming pools per area and accounts for the largest ratio of evaporation per unit area. As the number of swimming pools has increased, water loss by evaporation has increased by nearly $32 \%$ over the last decade. Evaporation and subsequent swimming pool re-filling represents nearly $5 \%$ of urban water use in the islands, and adds $9.6 \mathrm{~L}$ of water consumption per guest night and person night. In Mallorca, yearly sums can account for one-third or one-half of the storage capacity of the two reservoirs located in the Tramuntana mountain range.

Evaporative losses from swimming pools located in the shade during some hours may decrease evaporation by $5 \%-10 \%$ relative to pools under full sun exposure over the course of a day. However, the latter results are only illustrative and may be worth investigating further to increase the accuracy of the water loss estimates from swimming pools. Water saving strategies targeting domestic demand can be complemented by considering these factors, although the highest water demand was coming from agriculture [10].

The calculated evaporation increase accounted for the proliferation of swimming pools but not for inter-annual changes in the atmospheric evaporative demands. During the study period, no particular trend in the atmospheric terms was observed. However, we did observe a trend over a longer period of time (i.e., the last 25 years), with an increase in the evaporative demand of $12 \mathrm{~mm}$ per year. Together with the increasing temperatures projected by climate models over future decades, these results should alert municipalities to the proliferation of swimming pools and the potential for water abuse in the islands. Further research may account for future evaporative losses under climate change scenarios in a likely warmer climate. A regional perspective is essential to appropriately frame our results. In addition, analyses performed at a finer spatio-temporal scale could improve water loss estimates. For example, by considering the local meteorological conditions (i.e., topographic effects, local winds, thermal inversions, or even the cooling effects of lawns and trees), the effects of water splashing, or the presence of leakages in the filtering systems. We seek to accomplish such considerations in future research in order to provide water managers and policymakers with insights into vital water saving improvements.

Our results should inform the Balearic population and policymakers about the pressures that proliferating swimming pools in the archipelago may exert on freshwater resources. Public debate over water savings strategies, such as the use of pool covers, drainage barriers, regional and tourism planning, or changing water tariff schemes, should be opened.

Supplementary Materials: The following are available online at http:/ /www.mdpi.com/2073-4441/10/12/1883/ s1, Table S1: Evaporative water losses from swimming pools by year and municipality (million L).

Author Contributions: Conceptualization, A.H. and E.M.-T.; methodology, E.M.-T. and J.L.-L.; data curation and validation, E.M.-T.; formal analysis, E.M.-T. and J.L.-L.; cartography, J.L.-L.; writing—original draft preparation, A.H.; writing—review and editing, A.H., E.M.-T., J.L.-L., and M.B.-S.; funding acquisition, M.B.-S. 
Funding: This research was funded by the Spanish Ministry of Economy and Competitiveness through the project "Crisis and restructuring of the Spanish tourist coast" (CSO2015-64468-P) and the European Regional Development Fund (ERDF).

Acknowledgments: AEMET (Agencia Estatal de Meteorología) provided climatological data free of charge under the terms and conditions of the meteorological services for non-lucrative investigational projects carried out by officially recognized research organizations. SEC (Sede Electrónica del Catastro) provided cadastral spatial and alphanumeric information. We thank the Geography students Macarena Arco, Pep Lluís López and Sebastià Massanet for their help with data processing.

Conflicts of Interest: The authors declare no conflict of interest. The funders had no role in the design of the study; in the collection, analyses, or interpretation of data; in the writing of the manuscript, or in the decision to publish the results.

\section{References}

1. Deyà Tortella, B.; Tirado, D. Hotel water consumption at a seasonal mass tourist destination. The case of the island of Mallorca. J. Environ. Manag. 2011, 92, 2568-2579. [CrossRef] [PubMed]

2. Kent, M.; Newnham, R.; Essex, S. Tourism and sustainable water supply in Mallorca: A geographical analysis. Appl. Geogr. 2002, 22, 351-374. [CrossRef]

3. Lorenzo-Lacruz, J.; Morán-Tejeda, E. Spatio-temporal patterns of meteorological droughts in the Balearic Islands (Spain). Cuad. Investig. Geogr. 2016, 42, 49. [CrossRef]

4. Lorenzo-Lacruz, J.; Garcia, C.; Morán-Tejeda, E. Groundwater level responses to precipitation variability in Mediterranean insular aquifers. J. Hydrol. 2017, 552, 516-531. [CrossRef]

5. Candela, L.; Wallis, K.J.; Mateos, R.M. Non-point pollution of groundwater from agricultural activities in Mediterranean Spain: The Balearic Islands case study. Environ. Geol. 2008, 54, 587-595. [CrossRef]

6. Essex, S.; Kent, M.; Newnham, R. Tourism Development in Mallorca: Is Water Supply a Constraint? J. Sustain. Tour. 2004, 12, 4-28. [CrossRef]

7. Garcia, C.; Servera, J. Impacts of tourism development on water demand and beach degradation on the island of mallorca (spain). Geogr. Ann. Ser. A Phys. Geogr. 2003, 85, 287-300. [CrossRef]

8. Viola, F.; Sapiano, M.; Schembri, M.; Brincat, C.; Lopez, A.; Toscano, A.; Diamadopoulos, E.; Charalambous, B.; Molle, B.; Zoumadakis, M.; et al. The state of water resources in major Mediterranean islands. Water Resour. 2014, 41, 639-648. [CrossRef]

9. Govern de les Illes Balears Plan Hidrológico de las Illes Balears 2015-2021. Memoria, Govern de les Illes Balears. Conselleria d'Agricultura, Medi Ambient i Territori. Available online: http:/ /www.caib.es / sacmicrofront/archivopub.do?ctrl=MCRST259ZI190912\&id=190912 (accessed on 15 October 2017).

10. Hof, A.; Blázquez-Salom, M.; Colom, M.C.; Périz, A.B. Challenges and Solutions for Urban-Tourist Water Supply on Mediterranean Tourist Islands: The Case of Majorca, Spain. In The Global Water System in the Anthropocene; Springer International Publishing: Cham, Switzerland, 2014; pp. 125-142.

11. Mantecón, A. Tourist modernisation and social legitimation in Spain. Int. J. Tour. Res. 2010, 12. [CrossRef]

12. Morote, Á.-F.; Saurí, D.; Hernández, M. Residential Tourism, Swimming Pools, and Water Demand in the Western Mediterranean. Prof. Geogr. 2017, 69, 1-11. [CrossRef]

13. Hof, A.; Blázquez-Salom, M. The Linkages between Real Estate Tourism and Urban Sprawl in Majorca (Balearic Islands, Spain). Land 2013, 2, 252-277. [CrossRef]

14. Gössling, S.; Hall, C.M.; Scott, D. Tourism and Water; Channel View Publications: Bristol, UK, 2015; ISBN 9781845414993.

15. Gössling, S.; Peeters, P.; Hall, C.M.; Ceron, J.-P.; Dubois, G.; Lehmann, L.V.; Scott, D. Tourism and water use: Supply, demand, and security. An international review. Tour. Manag. 2012, 33, 1-15. [CrossRef]

16. Gober, P.; Quay, R.; Larson, K.L. Outdoor Water Use as an Adaptation Problem: Insights from North American Cities. Water Resour. Manag. 2016, 30, 899-912. [CrossRef]

17. Domene, E.; Saurí, D. Urbanisation and Water Consumption: Influencing Factors in the Metropolitan Region of Barcelona. Urban Stud. 2006, 43, 1605-1623. [CrossRef]

18. Morote, Á.-F.; Hernández, M. Urban sprawl and its effects on water demand: A case study of Alicante, Spain. Land Use Policy 2016, 50, 352-362. [CrossRef]

19. Wentz, E.A.; Gober, P. Determinants of Small-Area Water Consumption for the City of Phoenix, Arizona. Water Resour. Manag. 2007, 21, 1849-1863. [CrossRef] 
20. Saurí, D. Water Conservation: Theory and Evidence in Urban Areas of the Developed World. Annu. Rev. Environ. Resour. 2013, 38, 227-248. [CrossRef]

21. Balling, R.C.; Gober, P.; Jones, N. Sensitivity of residential water consumption to variations in climate: An intraurban analysis of Phoenix, Arizona. Water Resour. Res. 2008, 44. [CrossRef]

22. Salvati, L.; Ridolfi, E.; Pujol, D.S.; Ruiz, P.S. Latent sprawl, divided Mediterranean landscapes: Urban growth, swimming pools, and the socio-spatial structure of Athens, Greece. Urban Geogr. 2016, 37, $296-312$. [CrossRef]

23. Vidal, M.; Domene, E.; Sauri, D. Changing geographies of water-related consumption: Residential swimming pools in suburban Barcelona. Area 2010, 43. [CrossRef]

24. Neunteufel, R.; Richart, L.; Perfler, R. Wasserverbrauch und Wasserbedarf. Auswertung empirischer Daten zum Wasserverbrauch; Bundesministerium für Land-und Forstwirtschaft, Umwelt und Wasserwirtschaft, Österreichischer Wasser-und Abfallwirtschaftsverband (ÖWAV): Wien, Austria, 2012.

25. Deyà-Tortella, B.; Garcia, C.; Nilsson, W.; Tirado, D.; Deyà-Tortella, B.; Garcia, C.; Nilsson, W.; Tirado, D. Analysis of Water Tariff Reform on Water Consumption in Different Housing Typologies in Calvià (Mallorca). Water 2017, 9, 425. [CrossRef]

26. Fisher-Jeffes, L.; Gertse, G.; Armitage, N. Mitigating the impact of swimming pools on domestic water demand. Water SA 2016, 41, 238. [CrossRef]

27. Claval, P. Evolving Forms of Mobility and Settlement. In Second Home Tourism in Europe: Lifestyle Issues and Policy Responses; Ashgate: Aldershot, UK, 2013.

28. Hof, A.; Schmitt, T. Urban and tourist land use patterns and water consumption: Evidence from Mallorca, Balearic Islands. Land Use Policy 2011, 28, 792-804. [CrossRef]

29. Penman, H.L. Natural evaporation from open water, hare soil and grass. Proc. R. Soc. Lond. A Math. Phys. Sci. 1948, 193, 120-145. [CrossRef] [PubMed]

30. Peterson, T.C.; Easterling, D.R.; Karl, T.R.; Groisman, P.; Nicholls, N.; Plummer, N.; Torok, S.; Auer, I.; Boehm, R.; Gullett, D.; et al. Homogeneity adjustments ofin situ atmospheric climate data: A review. Int. J. Climatol. 1998, 18, 1493-1517. [CrossRef]

31. Preciado, J.S. Metodología para medir la estructura urbana de la ciudad actual, utilizando la base de datos del catastro. Aplicación al sector suroeste de la Comunidad de Madrid. Boletín la Asoc. Geógrafos Españoles 2015. [CrossRef]

32. Bueno, T.M. Breve crónica de un siglo de Catastro en España (1906-2002). CT Catastro 2008, 63, 31-60.

33. Direcció General del Catastro. Sede Electronica del Castro. Available online: https:/ / www.sedecatastro.gob. es (accessed on 1 March 2017).

34. Shuttleworth, W. Evaporation. Chapter 4. In Handbook of Hydrology; Maidment, D.R., Ed.; McGraw-Hill: New York, NY, USA, 1993.

35. Guo, D.; Westra, S.; Peterson, T. Evapotranspiration: Modelling Actual, Potential and Reference Crop Evapotranspiration. In R Package Version; 2017; Available online: https:/ /CRAN.R-project.org/package= Evapotranspiration (accessed on 17 July 2017).

36. Allen, R.G.; Pereira, L.S.; Raes, D.; Smith, M. Crop Evapotranspiration-Guidelines for Computing Crop Water Requirements-FAO Irrigation and Drainage Paper 56; FAO: Rome, Italy, 1998.

37. Hargreaves, G.H.; Samani, Z.A. Estimating potential evapotranspiration. J. Irrig. Drain. Div. 1982, 108, 225-230.

38. Mardikis, M.G.; Kalivas, D.P.; Kollias, V.J. Comparison of Interpolation Methods for the Prediction of Reference Evapotranspiration-An Application in Greece. Water Resour. Manag. 2005, 19, 251-278. [CrossRef]

39. Ochsenbauer, C. Sportstättenstatistik der Länder: Bestand und Sanierung von Frei- und Hallenbädern. Arch. des Badewesens 2003, 56, 298-300.

40. EMAYA. Available online: www.emaya.es (accessed on 15 October 2017).

41. Azorin-Molina, C.; Vicente-Serrano, S.M.; Sanchez-Lorenzo, A.; McVicar, T.R.; Morán-Tejeda, E.; Revuelto, J.; El Kenawy, A.; Martín-Hernández, N.; Tomas-Burguera, M. Atmospheric evaporative demand observations, estimates and driving factors in Spain (1961-2011). J. Hydrol. 2015, 523, 262-277. [CrossRef]

42. Giorgi, F.; Lionello, P. Climate change projections for the Mediterranean region. Glob. Planet. Chang. 2008, 63, 90-104. [CrossRef] 
43. Stocker, T. Climate Change 2013: The Physical Science Basis: Working Group I Contribution to the Fifth Assessment Report of the Intergovernmental Panel on Climate Change; Cambridge University Press: Cambridge, UK, 2013; ISBN 9781107057999.

44. Spinoni, J.; Vogt, J.V.; Naumann, G.; Barbosa, P.; Dosio, A. Will drought events become more frequent and severe in Europe? Int. J. Climatol. 2018, 38, 1718-1736. [CrossRef]

45. Eurostat. Medstat II: Water and Tourism' Pilot Study; Office for Official Publications of the European Communities: Luxembourg, 2009.

46. Govern de les Illes Balears Portal de l'Aigua de les Illes Balears. Sumministre i consum urbà d'aigua a les Illes Balears per Terme Municipal. Available online: https:/ / www.caib.es/sacmicrofront/archivopub.do? ctrl=MCRST259ZI155299\&id=155299 (accessed on 7 February 2017).

47. Shah, M.M. Prediction of evaporation from occupied indoor swimming pools. Energy Build. 2003, 35, 707-713. [CrossRef]

48. Asdrubali, F. A scale model to evaluate water evaporation from indoor swimming pools. Energy Build. 2009, 41, 311-319. [CrossRef]

49. Trip Advisor. Available online: https://www.tripadvisor.com/HotelsList-Majorca-Resorts-With-IndoorPools-zfp10850262.html (accessed on 20 November 2018).

50. Molina Martínez, J.M.; Martínez Alvarez, V.; González-Real, M.M.; Baille, A. A simulation model for predicting hourly pan evaporation from meteorological data. J. Hydrol. 2006, 318, 250-261. [CrossRef]

51. Gallego-Elvira, B.; Baille, A.; Martín-Górriz, B.; Martínez-Álvarez, V. Energy balance and evaporation loss of an agricultural reservoir in a semi-arid climate (south-eastern Spain). Hydrol. Process. 2010, 24, 758-766. [CrossRef]

52. March, H.; Sauri, D. When sustainable may not mean just: A critical interpretation of urban water consumption decline in Barcelona. Local Environ. 2017, 22, 523-535. [CrossRef]

(C) 2018 by the authors. Licensee MDPI, Basel, Switzerland. This article is an open access article distributed under the terms and conditions of the Creative Commons Attribution (CC BY) license (http:/ / creativecommons.org/licenses/by/4.0/). 